\title{
CERTAIN ISSUES OF TEACHING THE GERMAN LANGUAGE AS THE SECOND FOREIGN LANGUAGE IN TECHNICAL HIGHER EDUCATIONAL INSTITUTION
}

\author{
ASUNTOS ESPECÍFICOS DE ENSEÑAR LA LENGUA \\ ALEMANA COMO LA SEGUNDA LENGUA \\ EXTRANJERA EN LA INSTITUCIÓN TÉCNICA \\ SUPERIOR
}

\author{
Valentina I. Chechetka', Lyudmila V. Lukina \\ ${ }^{1}$ Voronezh State Technical University (Voronezh), Ph.D. of Philology, \\ Associate Professor, Associate Professor of the Department of Foreign \\ Languages and Translation Theory \\ e-mail: ChechetkaValentina@yandex.ru \\ ${ }^{2}$ Voronezh State Technical University (Voronezh), Ph.D. of Philology, \\ Associate Professor, Associate Professor of the Department of Foreign \\ Languages and Translation Theory \\ e-mail:lookyna@gmail.com
}

Enviado: 27 de junio de 2019

Aceptado para publicar: 30 de julio de 2019

Publicado: 8 de agosto de 2019

\section{abstract}

Formulation of the problem. The article considers various approaches and methods for teaching German as the second foreign language offered by domestic and foreign scientists testifying to the need for additional comprehension and refinement of the main principles for teaching German as the second foreign language after learning English. The linguistic characteristics of English and German are analyzed at the phonetic, grammatical and lexical levels.

Results. The theoretical analysis of the factors for teaching and learning German as the second language is given. It allowed us to reveal the following principles as fundamental ones: the principle of support and comparative connection with the first foreign and native languages, the principle of individualization of teaching, as well as the cognitive principle. It was found out how to approach the organization of the content of teaching, forms and methods of teaching so that students acquire explicit and implicit experience in the formation and improvement of teaching strategies. The study proved that parallel learning of the English and German languages has special advantages for learners based on the linguistic similarity of these two languages.

Conclusions. The theoretical and practical analysis of the factors for teaching and learning German as the second language allowed us to reveal the following principles as fundamental ones: the principle of support and comparative connection with the first foreign and native languages, the principle of individualization of teaching, as well as the cognitive principle. The analysis allowed us to understand how to approach the organization of the content of training, forms and methods of teaching, so that students acquired explicit and implicit experience in the formation and improvement of teaching strategies. The study also clearly demonstrated that the parallel learning of the English and German languages had special advantages for learners, based on the linguistic similarity of these two languages.

Keywords: second foreign language; linguistic peculiarities of the language; phonetic, grammatical, lexical levels; contrast, comparison and analysis at the level of the linguistic system; cultural phenomena.

Formulación del problema. El artículo considera varios enfoques y métodos para enseñar alemán como la segunda lengua extranjera ofrecida por científicos nacionales y extranjeros que dan testimonio de la necesidad de una comprensión y refinamiento adicionales de los principios fundamentales para enseñar alemán como segunda lengua extranjera después de aprender inglés. Las características lingüísticas del inglés y el alemán se analizan a nivel fonético, gramatical y léxico.

Resultados Se proporciona el análisis teórico de los factores para enseñar y aprender alemán como segunda lengua. Nos permitió revelar los siguientes principios como fundamentales: el principio de apoyo y conexión comparativa con las primeras lenguas extranjeras y nativas, el principio de individualización de la enseñanza, así como el principio cognitivo. Se descubrió cómo abordar la organización del contenido de la enseñanza, las formas y los métodos de enseñanza para que los estudiantes adquieran experiencia explícita e implícita en la formación y mejora de las estrategias de enseñanza. El estudio demostró que el aprendizaje paralelo de los idiomas inglés y alemán tiene ventajas especiales para los alumnos en función de la similitud lingüística de estos dos idiomas.

Conclusiones El análisis teórico y práctico de los factores para enseñar y aprender alemán como segunda lengua nos permitió revelar los siguientes principios como fundamentales: el principio de apoyo y conexión comparativa con las primeras lenguas extranjeras y nativas, el principio de individualización de la enseñanza, así como el principio cognitivo. El análisis nos permitió comprender cómo abordar la organización del contenido de la capacitación, las formas y los métodos de enseñanza, de modo que los estudiantes adquirieran experiencia explícita e implícita en la formación y mejora de estrategias de enseñanza. El estudio también demostró claramente que el aprendizaje paralelo de los idiomas inglés y alemán tenía ventajas especiales para los estudiantes, basado en la similitud lingüística de estos dos idiomas.

Palabras clave: segunda lengua extranjera; peculiaridades lingüísticas de la lengua; niveles fonéticos, gramaticales, léxicos; contraste, comparación y análisis a nivel del sistema lingüístico; Fenómenos culturales. 


\section{Introduction}

The study of a second foreign language in the system of higher education of the Russian Federation is becoming more urgent and demanding. This is due to the modern educational trends: the preparation of competitive Russian specialists able to represent and protect the results of the innovative engineering activities in foreign language; increasing academic mobility; the internationalization of the Russian higher education as a whole.

The choice of German as the second language at a technical University is not accidental, and it is relevant for many Russian regions. The ratification of the provisions of the Bologna Agreement in the Russian Federation and in Germany in 2010 promoted the intensification of the interaction, strengthening and expanding cooperation between Russian and German Universities. German is the second most important language in the scientific field. It should also be emphasized that Germany ranks third in the world in its contribution to scientific-and-research developments, and it allocates scholarships to foreign scientists for researches. Therefore, Germany is most open to Russian specialists in the field of education, science, improving qualification, and it is one of the most important target regions and a promising partner for Russian Universities and enterprises [1].

\section{Methodology of the Study}

The article deals with the investigation of the comments on the study of German as the first and/or second foreign language (after learning English) at a technical higher educational institution. The subject of the investigation is the linguistic characteristics of the English and German languages at the phonetic, grammatical and lexical levels.

The material for the research is the lexical corpus of the German and English languages, the Large German-Russian Dictionary, the Oxford English Dictionary, and on-line dictionaries.

Methods of research. When conducting the research, the methods of observation, interpretation and semantic analysis of linguistic units have been used.

\section{Results of the Study}

As a result of the conducted research, it has been established that the tool for realizing the goal and the main tasks for teaching German as the second foreign language is the methodology, which is common for modern teaching foreign languages, supplemented by a set of specific principles applicable to the teaching the English language. The theoretical and practical analysis of the factors for teaching and studying German as the second language allowed us to reveal the following principles as fundamental ones: the principle of support and comparative connection with the first foreign and native languages, the principle of individualization of teaching, as well as the cognitive principle. The analysis allows us to understand how to approach the organization of the content of training, forms and methods of teaching, so that students can acquire an explicit and implicit experience in the formation and improvement of teaching strategies. The research also clearly demonstrated that the parallel learning of the English and German languages has special advantages for learners based on the linguistic similarity of these two languages.

The experience of teaching the German language (hereinafter GL) on the basis of English (hereinafter EL) in technical Universities shows that the successful mastering of German as the second foreign language is facilitated by some linguistic peculiarities of the language, namely:

1) the Latin written language;

2) the presence of the common layer of the vocabulary of the German origin;

3) some common points in pronunciation;

4) the presence of grammatical phenomena, similar in structure and semantics;

5) similarity of speech patterns, which are studied at the initial stage.

The problems of teaching a second foreign language is given enough attention in didactics and methods of teaching $[2,3]$. In recent years, the search for rational principles and effective methods of teaching has been significantly increased, a number of important psychological and methodological studies have been carried out $[4-7,16,17]$. In our opinion, the views of modern Germanists on the modern approaches and principles of teaching German as the second language in non-linguistic Universities are of particular interest. Dietmar Resler believes that the basis for teaching German as the second foreign language, first of all, should be the similarity between the languages: the mutual influence of cultures and languages, speech borrowings, grammatical structures [8]. The meeting with the German language should have an obligatory "social intercultural aspect", which can later be successfully used in future professional activities. On the contrary, Gerhard Stikel is of the opinion that teaching German as the second foreign language should be based on "the contrasts with other languages" [9]. At the same time, the main emphasis is placed on "the complex moments": grammar, morphology and syntax, which is well traced when compared with the English texts. The scientist repeatedly 
emphasizes in his writings that the excellent assimilation of the grammar and vocabulary of the German language is unsuccessful without the external and internal motivation of the learner.

The variety of the approaches and methods for teaching the GL, offered by domestic and foreign scientists, testifies to the need for additional comprehension and refinements of the basic principles for teaching German as the second foreign language after learning English. First of all, it is the definition of the purpose for teaching the GL in a technical higher educational institution. The center of the process of teaching German as the second foreign language in a technical University is the formation of the intercultural communication necessary and sufficient for elementary communication at the domestic, academic and professional levels. For comparison, the purpose of the language training program in German as the first foreign language in a technical university is the formation and development of intercultural professionally oriented communicative competence that allows graduates to integrate into the international professional and scientific media. Comparison of the goals for teaching the EL and the GL as the first or second foreign language allows us to conclude that they are analogous in the paradigm of the communicative and intercultural approaches, which is also relevant, in our opinion, for the principles of education, which are confirmed by the fact that "the system of bilingual education can be effective one only if its components are connected by the unity of the methodological principles"[6].

Thus, when teaching the GL, the case in point should not be about creating an entirely new didactic-and-methodological concept or paradigm, but about determining the particular conditions of the implementation and the factors influencing the teaching and learning of German as the second foreign language. Such determinative factors include:

- the peculiarities of linguistic and regional geographical material;

- peculiarities of the target group;

- the conditions for teaching and studying.

The peculiarities of the linguistic and regional geographical material of the German and English languages stipulate for singling out the principle of support and comparative connection with the English and native languages of students as one of the key principles of teaching the German language.

As the practice of teaching shows, the presence of even elementary knowledge of English permits students to master the German language faster and more effectively, which is due to the genetic proximity of these languages. The interaction of the EL and the GL requires special attention, since along with unifying characteristics one cannot but note a number of characteristic differences, more pronounced at different levels. Consider it in more detail.

1. Phonetic level: stress in words, intonation in sentences and spelling.

As for phonology, the sounds of the EL and the GL are very similar, as well as the stress and the intonation. However, for example, the sound [D] in the words this, thing, that does not exist in German, and many people have some problems in pronouncing such words. German words beginning with " $\mathrm{w}$ " are pronounced with the [v] sound. This explains the incorrect pronunciation of such English words as we, wine as $v$ and vine. In studying a second foreign language, it is also important to proceed from all the sorts of comparisons: letters (the presence of vowels and consonants), length and shortness of vowels, letter combinations, double consonants, etc. All these phenomena are present both in the EL and in the GL. Compare:

- the double consonant is pronounced with one consonant sound: [g], [p] (digging, Lippe);

- the vowels differ in length and shortness: sleepslip, Lid-Lied;

- the presence of diphthongs: English: [ei], [ai], [oi], [au], [əu], [ia], [uə], [eə]; German: ei, ai, eu, äu.

It is particularly remarkable, that in both languages there are diphthongs [ei], [ai], [oi]. Since in the GL, there are no rules for reading the vowel letters in the stressed syllable, it is enough to master the reading of letters and certain letter combinations to read German.

On the other hand, it is impossible to exclude the possibilities of appearing incorrect analogies i.e. an incorrect transfer of some phenomenon from another language, for example, incorrect stress or reading some letters and word combinations. For example, in the English word "technology", the stress falls on the second "o" sound, and in German, "Technologie" has the stress on the last syllable. Moreover, in these words one and the same grapheme "ch" is read and pronounced in different ways. In the German version, this is the sound $[\boldsymbol{x}]$, in English - $[\boldsymbol{k}]$. Therefore, when studying the GL as the second foreign language, one should pay attention to certain peculiarities of reading.

Consider some peculiarities of reading in the two languages:

a) in the EL, the vowel $\mathbf{e}$ at the end of the word, as a rule, is not readable; in the GL, there is no such an unpronounceable vowel at the end of the word:

\begin{tabular}{ccc} 
& English & word \\
\hline German word & machine \\
\hline
\end{tabular}


Maschine

\begin{tabular}{ll} 
& cigarette \\
\hline Zigarette & Tribune \\
Tribüne &
\end{tabular}

b) in the EL, a long vowel sound is shown by a double vowel or a combination of vowels, and in the GL except for a double vowel, the length may also be indicated by the letter $\mathbf{h}$ standing after the vowel:

German word English word

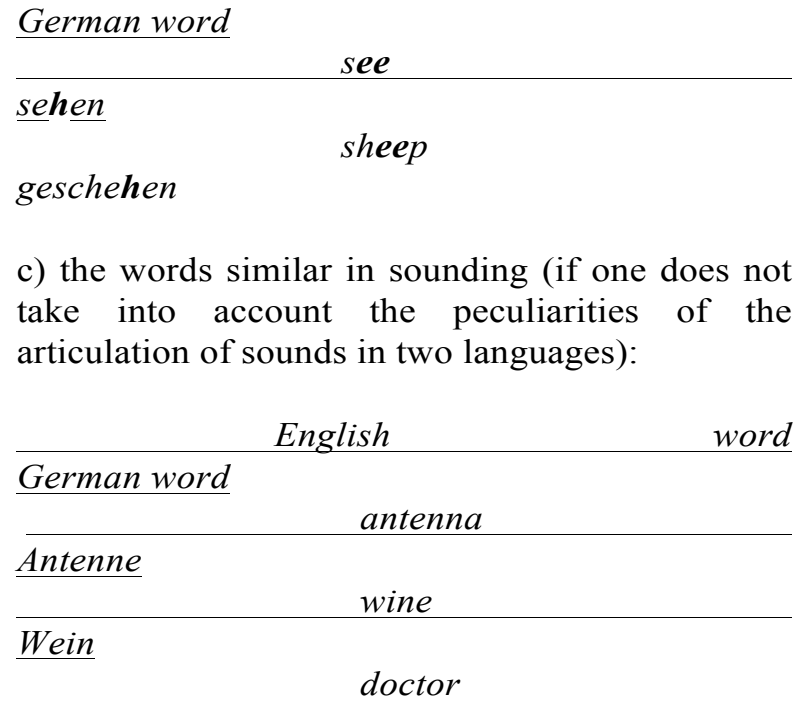

Doktor

d) the words differing in reading of the stressed vowel or vowel letters combinations:

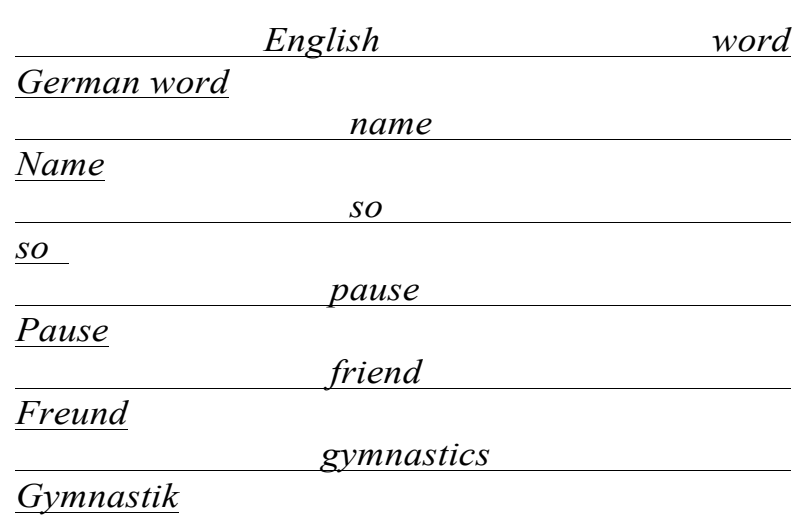

e) the words differing in displacing stress:

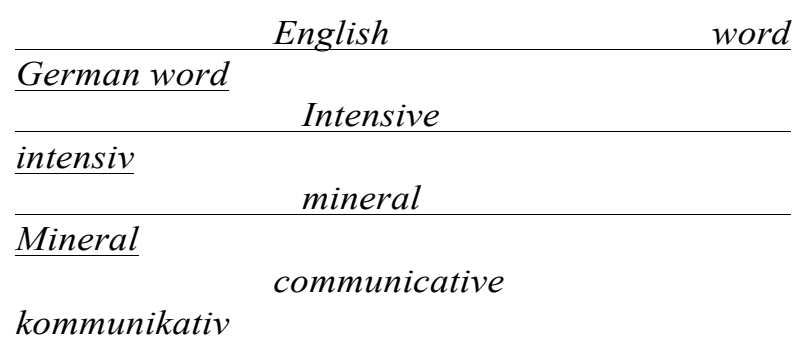

f) the verbs ending with a consonant or an unpronounceable vowel in the EL and always ending with - (e)n in the GL:

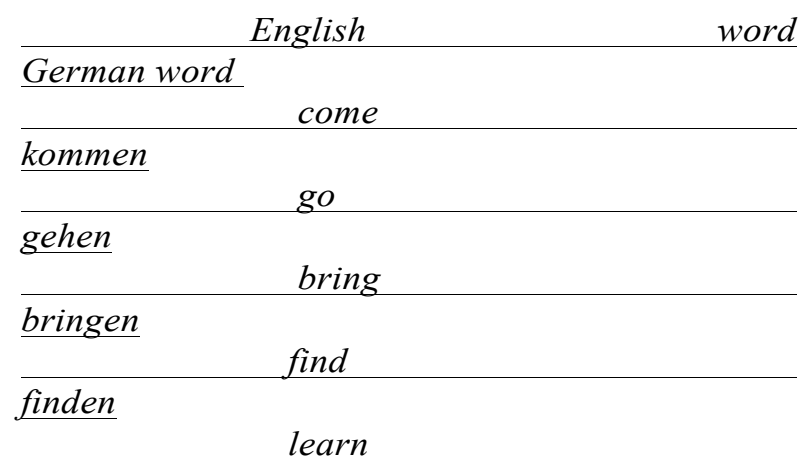

lernen

Thus, the knowledge and skills acquired during the study of the first foreign language (EL) are an additional reference material, with which it is very convenient not only to draw analogies, but also to pay great attention to the differences between the languages. Therefore, it is quite easy to assimilate reading German. It is only necessary to pay attention to some peculiarities of reading.

2. The grammatical level: the article, the frame construction of sentences, the order of words in complex sentences, etc.

Consider some grammatical similarities and differences between the EL and the GL. One of the common problems for students learning the GL is the choice of the right tense for talking about the past. Usually in the colloquial GL, the present perfect time is used when talking about past events: Dann bin ich in die Universities gegangen. The same tense is also used in English: Then I have gone to the University.

Note that the German language is inflected. This means that most parts of speech are changed according to their function in a sentence. In English, to a large extent, the word remains unchanged.

German has three functions of the word order in sentence that do not exist in English [3, 4]:

1. First, the main verb should be the second element in sentence. This often requires the inversion of the subject and the verb. For example: Manchmal komme ich mit dem Bus in die Universität. (English: Sometimes I come to the University by bus.).

2. Secondly, the main verb should be the last element in the subordinate clause. For example: Sie fragte mich, weil ich zuviel Coffee getrunken habe. (English:I feel bad because I have drunk too much coffee).

3. Thirdly, the past participle should be the last element in sentence. For example: Ich habe ihn nicht gesehen. (English: I have not seen him.).

It should also be emphasized that the German language does not revoke the case system. The English sentence: "An old woman gave an apple to a little girl" can be expressed in German by the following ways: 
a) Eine alte Frau gab einem kleinen Mädchen einen Apfel.

b) Einem kleinen Mädchen gab eine alte Frau einen Apfel.

c) Einen Apfel gab eine alte Frau einem kleinen Mädchen.

There are also grammatical correspondences in the formation of the Comparative and Superlative Degrees of Comparison of Adjectives in modern English and German.

For example, to form the Comparative Degree of Adjectives and of most Adverbs in English and German, the suffix -er is added, for example: dick / dicker (thick / thicker), klein / kleiner (small / smaller).

To form the Superlative Degree in both languages, the suffix -est is used, and in German, the ending " $e$ " is often added to the end of the adjective: (der) dickste (the thickest), (das) kleinste (the smallest). Compare:

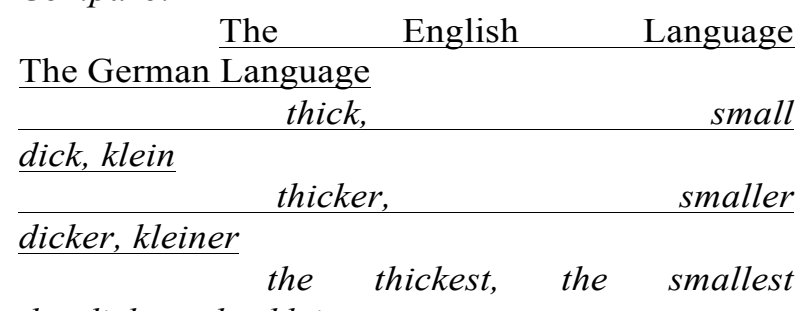

der dickste, das kleinste

The similarities and exceptions are observed when the Degrees of Comparison are not formed by the rule. For example, English: good - better - the best, German: gut - besser - (am) best (en) or much - more - the most, German.: viel - mehr - am meisten.

However, as opposed to English, the German language never uses "mehr (more)" with the other attribute to form a comparison. In English, "more" is used to form the Comparative Degree of Adjectives with two or more syllables: more beautiful, more intelligent, more interesting. And in German, the ending "-er" is always used for this purpose: schöner, intelligenter. Consider the following examples:

The English Language

My sister is not so tall as I am.

Meine Schwester ist nicht so gro $\beta$ wie ich.

His car is much more expensive than my car. Sein Auto ist viel teurer als mein Auto.

We prefer to travel by train.

Wir fahren lieber mit der Bahn.

Karl is the oldest.

Karl ist der Älteste. (Karl ist am ältesten.)

He likes to play basketball, but most of
Er spielt gern Basketball, aber am

all, he likes to play soccer.

liebsten spielt er Fussball.

Most people do not drive as fast as he does. Die meisten Leute fahren nicht so schnell wie er.

Grammatical correspondences in the EL and in the GL can also be traced in the verb system. Not only the ways of forming the Past Tense, but also the formation of some irregular verbs are similar. Compare:

\begin{tabular}{|c|c|c|}
\hline $\begin{array}{c}\text { The } \\
\text { The Gexman }\end{array}$ & English & Language \\
\hline The German Language & & \\
\hline lachen-lachte & laughed & \\
\hline sing & ing-sung & \\
\hline singen-sang-gesungen & & \\
\hline give & gave & given \\
\hline $\begin{array}{r}\text { geben - gab-gegeben } \\
\text { fall-f } \mathrm{f}\end{array}$ & l-fallen & \\
\hline fallen-fiel-gefallen & & \\
\hline lieben-liebte & - & ved \\
\hline
\end{tabular}

It should also be emphasized that the numerical system in both languages is similar. For example, the numbers from 10 to 20 are formed in the same way, unlike Russian, Spanish or French. Compare: English: ten, eleven, twelve, thirteen, fourteen, fifteen, sixteen, seventeen, eighteen, nineteen, twenty. German: zehn, elf, zwölf, dreizehn, vierzehn, fünfzehn, sechzehn, siebzehn, achtzehn, neunzehn, zwanzig.

Note also some other similar grammatical peculiarities:

- the use of articles; their classification into the definite/indefinite article (an egg / ein Ei; the Sun / die Sonne);

- the need for a verb-copula (She is ill / Sie ist krank);

-the presence of prefixes for some verbs; to the prefixes of the German verbs, there correspond the particles of English phrasal verbs (cf.: take off, sit down; ein $\backslash$ laden, ab \holen);

- the concept of modality and the specific character of using modal verbs, etc.

3. The lexical level.

Consider some similarities and differences in using lexical units in the two languages. Compare: card / Karte.

In the EL and in the GL, it has the following meanings:

1) a playing card,

2) a postcard.

3) a visiting card,

4) a plastic card.

However, the German word Karte $(f)$ is also used in the meaning of a ticket to the cinema, theater, and the English word card is not used in this sense, the word ticket is used for this meaning. 
Another example: Handy - mobile phone (GL), in the EL, the adjective handy means accessible; close, comfortable; useful; easily manageable, skillful, deft, but it has no meaning of "phone".

It is interesting to note that many words in the EL and in the GL have a great similarity. Cf.: "I am eating an apple, you are drinking milk" and "Ich esse einen Apfel, du trinkst Milch". Even without knowing the exact translation of the words, their meaning can be easily guessed. In our opinion, noteworthy are the Americanisms (Party, HipHop) and the Germanisms (Kindergarten / kindergarten). These borrowings make the language more accessible for understanding and help to get the feel of new surroundings. In addition, we cannot fail to mention another layer of vocabulary - internationalisms. For example, the word "taxi" (Taxi / taxi).

The explication of these differences, the conscious and purposeful comparison, the analysis of the phenomena at the level of the linguistic system, as well as the cultural phenomena, and the formation of strategies for working with them help to overcome the interference and to more rationally and optimally organize teaching the German language.

As to the role of the native language in the study of German as the second foreign language, it is important to note the following fact: Russian and German are not cognate. Therefore, one can rely on the support of the native language, in our case of Russian, only in the situations where it is methodically and didactically worthwhile. Thus, the reliance on English, belonging like German to the Germanic group of languages, is more rational than the reliance on the Russian language belonging to the Slavonic group [3,15].

Consider the following factor, which influences the specific character of studying and teaching German as the second language - the peculiarities of the target group. Here, the principle of individualization is placed in the forefront. The need to take this principle into account in teaching a second foreign language has been proved in the works by S.V. Barinova, V.I. Chechetka, G. Neuner, etc. $[6,10,11]$, This principle presupposes the consideration of the individual peculiarities of students in fulfilling communicative tasks, providing students with an opportunity to orient themselves on their needs and interests and to perform differentiated tasks. Our observations show that students of technical Universities choose the GL as the second language not only for broadening their outlook and raising their educational level, but also for acquiring specific knowledge and competencies needed in the present and future. In this case, they pose limited goals before themselves and before their teachers which are related to their professional and scientific activity and academic mobility. Learners are oriented themselves to their real needs, this fact explains the high level of conscious motivation to learn a second foreign language. The autonomy of learners is connected with their readiness and habits to independently and energetically work and with their ability to evaluate their linguistic-and-cultural experience and, if necessary, to correct it, to make independent and their own decisions and also to take responsibility for the results of learning the language. Here, an important role is played by creative assignments, project work, situations in which learners must take responsibility for the results and the quality of realizing the overall group tasks $[5,13,14]$. It should also be emphasized that the principle of individualization does not contradict the importance of the group work in the autonomous teaching.

In the conditions of cooperation, complex thought problems are more successfully solved, and new material is better assimilated. In turn, the implementation of individual and differentiated (in terms of complexity, subject, objectives and tasks depending on the needs of a particular student) tasks develops the skills for independent work on the language, the ability to work with reference literature, to independently arrange and transmit the information received to others, it develops thinking and creative abilities of students [6]. Teaching methods realized in the context of an autonomous approach on a conscious basis, develop the independence of thinking and action, the desire to control and evaluate their own learning.

It is also worth mentioning the determinative factor - a limited time period and the presence of students' experience in learning the foreign language. Consider it in more detail. The traditional approach to solving this problem is the reduction volume of the material being studied, a quick and concise presentation of new material, limitation of time for exercises, the reduction or lack of time for reviewing. This approach often leads to the demotivation of students to learn the foreign languages and thus, makes it difficult to achieve the main goal.

Thus, when teaching the EL and the GL, the need to develop intensive strategies and techniques, ways and methods for teaching and learning foreign languages is obvious. When developing them, one must proceed from the fact that students already know the basic linguistic phenomena (for example, grammatical phenomena: elementary sentence structures, personal and possessive pronouns, formation of plural number, negation, etc.). In addition, the learning process of the second foreign language, in our case German, should be based on the activation of cognitive processes: association, comparison, contrast, search, analysis, etc. Therefore, the cognitive 
principle in teaching a second foreign language is an absolute necessity for intensifying the learning process in the conditions of a limited number of hours devoted to the study of the FL[3, 4, 12].

\section{Conclusions}

Summarizing the above, we can draw the following conclusions: the means for realizing the goal and the main tasks for teaching German as the second foreign language is the methodology common to modern foreign language teaching, supplemented by a set of specific principles applicable to the teaching of English. The theoretical analysis of the factors for teaching and learning German as the second language allowed us to reveal the following principles as the fundamental ones: the principle of support and comparative connection with the first foreign and native languages, the principle of individualization of teaching, as well as the cognitive principle. The analysis allows us to understand how to approach the organization of the content of training, forms and methods of teaching, so that students can explicitly and implicitly acquire the experience in the formation and improvement of the teaching strategies. Our investigation shows that parallel learning of the English and German languages has special advantages for learners, based on the language similarity of these two languages.

\section{References}

1. V.I. Chechetka, L.A. Arens On the AllRussian Educational Forum "Multilingualism in Education: German the First Second Foreign Language", organized by the Goethe-Institut at the German Embassy in Moscow in cooperation with the Interregional Association of Teachers and Teachers of the German Language (IAUPN) on 19 and 20 November 2016 in Moscow / V.I. Chechetka // Scientific Newsletter Voronezh. State. Civil Engineering University. Modern Linguistic and Methodical-and-Didactic Studies. - 2017. Vol. 1 (33). - P. 188-191.

2. G.I. Voronina and et.al. Theory and practice of teaching German as the second foreign language. - Moscow: APK and PRO, 2003. - 68 p.

3. O.M, Ryabtseva Learning the German language as the second foreign language in a technical University // O.M. Ryabtseva // Proceedings of the Southern Federal University. Technical sciences. No. 10 (147), 2013. - P. 121-125.

4. S.V. Kuznetsova, I.E. Levina. Similarities of the English and German languages // Language, society, education // Interuniversity collection of scientific articles. Under the general editorship of N.A. Pavlova, B.V. Nikolaev. Penza, 2015. - P. 36-42.
5. Girenko I.V. On the Peculiarities of Teaching German as the Second Foreign Language on the Basis of English in Technical Universities [Electronic resource]. http://www.rusnauka.com/3._KAND_2007 /Philologia/18893.doc.htm (reference date: September 20, 2017).

6. S.V. Barinova. Innovative Technologies in Teaching Foreign Languages: Principles of Constructing an Optional Course "Second Foreign Language in School and University" [Electronic resource]. URL: http://festival.1 september.ru/authors/210482-920/ (reference date: September 21, 2017).

7. N.K. Ivanova Russian Language Policy: Problems and Perspectives $/ 7$ Foreign Language in a Technical University: Problems and Perspectives of Teaching: Proceedings of the Scientific and Practical Conference, June 4-5, 2009 / comp. N.K. Ivanova; Ivan. State. Chem.-Technol. Unty. Ivanovo, 2009. - 117 p.

8. Rösler D. Fremdsprachenerlernen in einem deutsch-sprachigen und nicht deutschsprachigen Land // DaF. - 2005. No. 2. - P. 75-80.

9. Stickel G. Deutsch von außen // DaF. 2005. - No. 3. - P. 115-117.

10. V.I. Chechetka. Some Aspects of the Teaching of the German Language as a Second Language in a Technical University /Chechetka V.I. // Scientific Newsletter. Series: Modern linguistic and methodical-and-didactic research.-2018.Vyp. 2 (38).-P. $92-102$.

11. Neuner G. Lernerautonomie und Lernstrategien: $\mathrm{zu}$ einer weiteren Fernstudieneinheit // Deutsch als Fremdsprache: Zeitschrift zur Theorie und Praxis des Deutschunterrichts für Ausländer. 2003. Heft 4. - S. 240-244.

12. Eslami, R., \& Ahmadi, S. (2019). Investigating the Role of Educational Media on Secondary School Students' Learning Process Improvement in Jahrom City. Journal of Humanities Insights, 3(01), 13-16.

13. Jabbari, E., Charbaghi, Z., \& Dana, A. (2019). Investigating the Effects of Educational and Motivational Education at Different Levels on the Performance and Application of dart throwing. Journal of Humanities Insights, 3(02), 37-44.

14. Kheirabadi, M. A., \& Mirzaei, Z. (2019). Descriptive valuation pattern in education and training system: a mixed study. Journal of Humanities Insights, 3(01), 712.

15. Upikang, B., \& Dogaheh, H. A. (2019). The Mental Health of Preschool Children and the Role of Instructors on them. Journal of Humanities Insights, 3(01), 3436.

16. Mendes, I. A., \& Silva, C. A. F. D. (2018). Problematization and Research as a Method of Teaching Mathematics. International Electronic Journal of Mathematics Education, 13(2), 41-55. https://doi.org/10.12973/iejme/2694

17. Ismail, I. B., Sabran, R., \& Mohamed Ariffin, M. Y. B. (2017). STUDY OF SITUATIONAL THEORY OF 
PROBLEM SOLVING (STOPS) IN

CONCEPTUALIZING FARMER'S

INFORMATION DELIVERY IN

MALAYSIA. Humanities \& Social

Sciences Reviews, 5(2), 124-133.

https://doi.org/10.18510/hssr.2017.528 